\section{FUNCTIONAL COLLABORATION IN WORLD AFFAIRS}

$\mathrm{T}$ HE survey of the activities of the Middle East Supply Centre which appears in the centenary number of the Economist is a valuable contribution to the discussions at present centring on the value of functionalism as a factor in promoting international collaboration. The success which has attended concentration on particular problems and the ease with which co-operation has been secured for some specific purpose, as the Hot Springs Conference showed, have suggested that functional co-operation may be a means of persuading the Powers ultimately to make the wide sacrifices in national sovereignty which the preservation of peace will demand. The Middle East Supply Centre is a piece of functional international machinery which has been evolved empirically and could be maintained in its own area after the War. It serves a natural regional grouping, which is overwhelmingly Arab, the industrial development of which has scarcely begun. The States are fiercely nationalist and the very fact that the Middle East is a microcosm makes its experience of value as a model for similar centres elsewhere.

While the war-time work of the Centre is chiefly to regulate the flow of supplies into the area in the interests of war economy, it needs little imagination to see the vital purpose which this simple piece of Anglo-American organization could serve after the War. Its staff is predominantly technical, scientific and young. Their chief work is to serve as a centre of information and contact, to advise, instruct and encourage the local authorities and to be, as it were, the guiding intelligence for the whole area. Already in this way the Centre has been a general transmitter of agricultural projects and improvements, facilitating the passage of successful experiments in agricultural development from one area to another. For example, it was only after the establishment of the Supply Centre that the excellent system of dealing with the menace of the goat to afforestation in Cyprust was brought to the notice of the Syrians, and successful experiments in growing seed potatoes have been extended from Malta and Palestine to other Middle East States.

This pooling and exchange of information is sup. ported by surveys carried out by experts from the Centre into local conditions of agricultural production, with comments on how they could be improved. The Centre has also arranged for the provision of agricultural machinery, and important schemes of irrigation have been sponsored. Three of these are being operated in Persia, another is under discussion for the headwaters of the Euphrates, while in Syria a scheme which had been considered for years was carried through by the 6lst Tunnelling Company of the South African Army at the request of the Middle East Supply Centre. Locust control is another example of international action planned through the Centre. Research has established the fact that these devastating insects execute a regular nomadic cycle through the Middle East, wintering in Southern
Persia, to return through Iraq, Syria and Egypt to Abyssinia. No one Government could ever have dealt with this vicious circle, but the Middle East Supply Centre has been able to bring all the interested States together and achieve the essential co-ordination. Under the direction of Dr. B. P. Uvarov in London and with the assistance of the R.A.F. and the Red Air Force, exterminating crusades, operating from the air and on land the length of the Red Sea and up through Persia and Iraq, hold promise that for the first time in history the plague may be brought under control.

Medical services provide another example, and here the experience of the International Health Organisation of the League of Nations had already pointed the way. Apart from the standardization of drugs and equipment, the Middle East Supply Centre has resulted in official medical services coming in contact, in the R.A.M.C. and the American services, with some of the finest medical minds of Britain and the United States. The standard of public health has already bein raised in this way, but scourges such as malaria offer opportunities for far more to be done.

These examples and others such as the creation of new industries or the assistance given to transport can scarcely fail to suggest to the scientific worker the value of the Centre after the War as a pool for all kinds of economic, social and technical services. In an area starved of technical efficiency, expert assistance would be always available without onerous political or economic conditions attached to its use, although the Governments concerned should be expected to contribute something in return for the advice they receive. Beyond this, the Centre would also be a planning headquarters. Its experts would conduct regularsurveys of areas or problems and advise the Governments on the best methods of solving their difficulties. Any problem which was beyond the competence of the local authorities or involved two or more Governments could be referred to the Centre for expert opinion. It needs little imagination to realize the immense contribution which the Centre could make in such ways through energy, guidance and clear thinking. Irrigation schemes, roads, power, artesian wells, industrial development, all crossing and recrossing national frontiers, could, as the Economist truly observes, give a unity to the Middle East which five generations of pan-Arabism could not achieve, if indeed it did not provide the kernel of effective political unity.

The significance of a Centre of this type, beginning as a piece of effective machinery for regional planning, co-operation and research, and stretching out to regional health services, transport authorities, public utilities, industrial and agricultural development boards, is not confined to its adoption, more or less modified, as a model for other centres and as a stimulus to functionalism. It has a profound bearing on the whole development of colonial policy and planning. The article in the Economist rightly stresses the opportunity which this functional approach to the problem of pooling sovereignty offers to Britain, and the need for ner to concentrate not on the export of business men and traders but on experts, tech. 
nicians, medical men and scientific workers, who combine her great and humane traditions with the scientific and technical skill the twentieth century requires. The point was indeed made by Flexner in his discussion of Englisil universities, when he emphasized the need of the British Commonwealth for trained men of wide disinterested cultural and scientific training, who could conduct organized attacks on the problems, practical and philosophical, of modern life. In that way might well come the creation of new markets, through the raising of standards of living everywhere, and the transition in Britain to a new industrial system based on highgrade products and services. But if colonial problems are no longer to be a stumbling block in international relations, if the question of access to raw materials is not to become academic, if commonwealth and empire are to be synonymous terms, colonial policy must take full account of these functional developments and turn them to the most effective use.

Much the same idea of functional development permeates the plea for imperial development on a much larger scale which is the essence of $H$. W. Foster and E. V. Bacon's "Wealth for Welfare". In urging the establishment of an imperial development authority which might be a prelude to an international authority, and would be organized on the lines of the public utility corporation, the emphasis is placed on the need for a factual approach, for continuity of policy and for adequate financial support. Whether in dealing with the economic development of a particular area such as British Honduras, which they use to illustrate their argument, or in describing the broad and more general work which might be entrusted to the proposed development authority, Messrs. Foster and Bacon stress the need for adequate research and experiment as a first stage. This must be the prelude to any extensive planning, and their suggestion that an exploratory research and development company should be formed first to acquire the knowledge and experience on which the organization of a permanent development authority could later be based, is characteristic of their outlook.

This scientific approach affords a sound basis for the conviction of Messrs. Foster and Bacon that economic development of the British Colonial Empire on lines primarily designed to promote welfare, and with resources and a long-term policy which will permit the cumulative benefit of the measures initiated to be reaped, is sound financially. What is striking is the extent to which their policy is already reflected in action. An article in the current number of the Round Table shows how the Hot Springs Conference has made an important addition to the technique of diplomacy and strengthened the collaboration of the United Nations. In a field where political action is also required to secure the solution of a technical or economic problem, it has done much to clear the way-so much that we might well encourage the idea of technical conferences as opposed to conferences of plenipotentiaries for clearing some of the ground in post-war problems.

Again, it is probable that the food organization is likely to serve as a source of technical and scientific advice to any commodity council set up by the United Nations as a political body to take executive action; and to secure a position of authority as an impartial source of information and advice in agricultural and nutritional matters may well be the most important part the food organization could play. By providing a meeting-ground for the expert and a forum for the discussion of matters of common concern, and by conducting expert inquiries or undertakings at the request of governments or groups of governments, such a body would be invaluable in furthering the aims of the Hot Springs Conference, irrespective of the progress which may be made in organizing economic relations internationally in more general fields.

The three notes struck in "Wealth for Welfare" are equally clearly reflected in Colonel Oliver Stanley's recent statements and speeches and in Government action. In regard to research, for example, the Colonial Economic Advisory Committee recently established under the chairmanship of the Duke of Devonshire to advise the Secretary of State on matters of economic policy in relation to the Colonial dependencies, particularly matters of general policy arising out of programmes of economic development, follows naturally on the Colonial Research Committe appointed last year under Lord Hailey as chairman. It should also be remembered that Nuffield College is at present engaged on a three and a half year scheme for research into economic and constitutional questions in British tropical Africa. A Committee of Colonial Studies set up to co-ordinate and advance these studies and an Institute of Colonial Studies, financed by Nuffield College, are among four further steps recently taken by the University of Oxford to develop Colonial studies. Again, the importance of comparative studies of labour problems as a field of research is well brought out by Dr. Margaret Reid in a paper, "Migrant Labour in Africa and its Effects on Tribal Life", in the International Labour Review $(45$, No. 6 ; 1942$)$ which has recently been reprinted. Dr. Reid's preliminary survey shows how labour demands of an alien economic enterprise have com. pletely undermined the old economic life of Nyasa. land and threaten its social life as well.

Colonel Stanley has explicitly recognized the importance of a factual basis for broad lines of economic policy, and he has emphasized in a speech in the House of Commons on July 13 and also else. where the necessity for liberal expenditure on colonial development; like Messrs. Foster and Bacon, he appears to be convinced of the value and importance of such expenditure on an adequate scale. He recog. nizes to the full the opportunity which the Colonial Development and Welfare Act offers, and his words on this point are the more important because he insists that economic development must be linked with educational advance, and that the two together form the twin pillars upon which any sound scheme of political responsibility must be based. This would appear to be the only way of combining the status of trustee with that of partner.

Colonel Stanley rightly pointed out that the spread 
of elementary education in the Colonies is a necessity for every social improvement; every economic development in some measure demands an increase of knowledge among the people. New health measures, the improvement of agrieultural methods, new cooperative machinery for production and distribution, and the establishment of secondary industries, make demands on the Colonial peoples for co-operation to which they can only respond when they have educational opportunities. The Commission of Inquiry into higher education in British West Africa under Mr. Walter Elliot, Mr. Justice Asquith's Commission of Inquiry into the whole question of university training in the Colonies, and the course for training in leadership of co-operative societies at the London School of Economics, are the natural concomitants if the expenditure of large sums from the Colonial Development and Welfare Fund contemplated by the Colonial Secretary is to bear full fruit.

On the question of regional developments, Colonel Stanley was as explicit as on this functional approach. While he recognizes that the detailed planning must be done on the spot, he stated that the experience already gained by the Anglo-United States Caribbean Commission has led the Government to contemplate more permanent machinery in which all the common problems of an area could be discussed. The Govern. ment would welcome the establishment of such machinery as the establishment of commissions for regions comprising not only the States with colonial territories in the region but also other States which have a major strategic or economic interest in the region. While each State would remain responsible for the administration of its own territory, such a commission would provide effective and permanent machinery for consultation and collaboration in promoting the well-being of the colonial territories, and with this work the people of the colonial territories in the region should be associated.

Colonel Stanley has thus associated himself with an idea to which General Smuts and Lord Hailey have given some prominence, and in the debate in the House of Commons Sir Edward Grigg stressed the opportunity in such international collaboration of associating the self-governing Dominions with the administration of the British Colonies. Even though the full responsibility of the tutelary Power of actual administration of a particular territory is unimpaired, there are clearly difficulties in regard to such groupings, as the slightest review of any possible groupings in Africa, for example, will show. None the less, the experience of the Middle East Supply Centre as well as that of Anglo-United States co-operation in the Caribbean has already indicated possibilities which must be explored. If we keep central direction to the planning of the broad schemes, ensuring continued, long-range planning and the provision of adequate resources, both in finance and in personnel, and entrust the elaboration and execution of detailed schemes to the local administration, we may best ensure the co-operation and interest of the individual communities and their leaders. At least it is clear that the co-operative attack on particular problems and the planning of resources to that end, independent of artificial political boundaries, may prove an indispensable step in the mobilization not merely of our scientific resources for the wise development of these untapped sources of agricultural or mineral wealth, but also in securing that widespread human interest and understanding without which no plans for the attack on disease, on ignorance, on malnutrition or on poverty can be pushed to a successful conclusion.

\section{TWO GREAT ARCHAOLOGISTS}

\section{Time and Chance}

The Story of Arthur Evans and his Forebears. By Joan Evans. Pp. $x i+410+15$ plates. (London, New York and Toronto : Longmans, Green \& Co., Ltd., 1943.) 21s. net.

7 HIS is rather the saga of a family than a biography of an individual. Out of a genealogical welter (considerately illuminated by two family trees on the end-papers) of Evanses, Dickinsons, Grovers, de Brissacs, and several other families, there emerges first the Rev. Arthur Benoni Evans, a somewhat ineffective schoolmaster with artistic tastes, and an incipient collector of coins; then John Evans, who combined great efficiency in his Uncle Dickinson's paper-making business with first-class pioneer work. in palæolithic archæology and in numismaties ; and thirdly, Arthur Evans, whose career as an amateur insurgent in Dalmatia and an omnivorous collector in many fields culminated in a blaze of glory as the discoverer of the ancient civilization of Minoan Crete. Along with these there are sketches of Anne (Dickinson), the capable wife who saved Arthur Benoni's ramshackle career from disaster; of John Evans' three wives, and his brother Sebastian, "impecunious, versatile, and happy", who took after his father in lack of practical effectiveness but achieved some reputation by his translation of the "High History of the Holy Grail" ; and of Arthur's brother, Lewis, whose fine collection of mathematical instruments adorns the Old Ashmolean building at Oxford. All these characters are admirably handled by Miss Evans, with a lightness of touch and a flavour of humour which commend and set off her mastery of her material.

The two outstanding figures, however, are, of course, John and Arthur, father and son, alike in their taste for antiquities, and in a flair in collecting which amounted almost to genius, but unlike in temperament and career. John worked hard in his somewhat unsympathetic uncle's business, earned: wealth, position, and a high reputation as a forceful member of countless committees and councils; and, as a sideshow, took a leading part in the earliest discoveries of palæolithic man, was a first-rate numismatist, became president of the Society of Antiquaries, the Numismatic Society, and the Geological Society, vice-president of the Royal Society, and a trustee of the British Museum, and filled his house with collections of all sorts of beautiful and interesting objects.

Arthur was far less a man of business, was something of a rolling stone and strongly individualist, but equally a born collector and an archæologist gifted with singular insight and initiative. After a fairly successful career at Harrow, where he got prizes for Greek epigrams, English essay, and English verse, but made few friends, and a first class in history at 